\title{
Orbital apocrine hidrocystoma with immunohistochemical confirmation
}

\author{
Hidrocistoma apócrino orbitário com \\ confirmação imunohistoquímica
}

Eduardo Damous Feijó ${ }^{1}$, Ana Carla de Souza Nery², Fábio Ramos Caiado³, Aline Maria Preihss, Paulo Henrique Borges Campos $^{3}$, Augusto Pereira ${ }^{5}$, Roberto Murillo Limongi ${ }^{6}$

\begin{abstract}
The authors report the first case in Brazilian literature of orbital apocrine hidrocystoma with immunohistochemistry confirmation. The tumor had been growing slowly and progressively, there was no history of impaired vision, diplopia, watering, discharge, or prior trauma. There was no proptosis and extraocular mobility was normal. The radiologic study by orbital computerized tomography revealed an extraconal nodule, with partially defined limits, with cystic and solid areas in the superomedial right orbit. An anterior orbitotomy, with full excision of the tumor was performed. A histopathology examination revealed apocrine hidrocystoma and immunohistochemistry confirmed the diagnosis. After surgery, the patient had total remission of symptoms.

Keywords: Hydrocystoma/diagnosis; Hydrocystoma/surgery; Orbit/surgery; Tomography, x-ray computed; Immunohistochemistry; Case reports
\end{abstract}

\section{ReSUMO}

Os autores relatam o primeiro caso de hidrocistoma apócrino orbitário com confirmação imunohistoquímica. O tumor apresentou crescimento lento e progressivo, sem relato de baixa de acuidade visual, diplopia, epífora, secreção ou trauma prévio. Não houve proptose ou alteração da motilidade extraocular. O exame de imagem por tomografia computadorizada da órbita revelou uma lesão nodular, extraconal, de limites imprecisos, com áreas císticas e sólidas no seu interior, na região súpero-medial de órbita direita. O paciente foi submetido à orbitotomia por via anterior, com exérese integral da tumoração. $\mathrm{O}$ exame histopatológico revelou o diagnóstico de hidrocistoma apócrino e a imunohistoquímica confirmou o diagnóstico. Após a cirurgia, o paciente teve regressão total dos sintomas.

Descritores: Hidrocistoma/diagnóstico; Hidrocistoma/cirurgia; Órbita/cirurgia; Tomografia computadorizada por raios x; Imunohistoquímica; Relatos de casos

\footnotetext{
1 Ocular Plastic Sector, Hospital Oftalmológico de Anápolis, Anápolis, GO, Brazil.

2 Ocular Plastic Sector, Instituto Panamericano da Visão, Goiânia, GO, Brazil.

${ }^{3}$ Hospital Oftalmológico de Anápolis, Anápolis, GO, Brazil

${ }^{4}$ Ophthalmology Service, Hospital Oftalmológico de Anápolis, Anápolis, GO, Brazil

${ }_{5}^{5}$ Anesthesiology Sector, Hospital Oftalmológico de Anápolis, Anápolis, GO, Brazil.

${ }^{6}$ Ocular Plastic Sector, Centro de Referência em Oftalmologia, Universidade Federal de Goiás, Goiânia, GO, Brazil.

Study carried out at the Ocular Plastic Sector of the Hospital Oftalmológico de Anápolis, Anápolis, Goiás, Brazil.

The authors declare no conflicts of interests.

Received for publication 12/09/2015 - Accepted for publication 01/12/2015
} 


\section{INTRODUCTION}

$\mathbf{H}$ idrocystomas are benign cystic lesions derived from sweat glands. Histologically, two types of hidrocystoma, eccrine and apocrine are recognized, reflecting the cells of origin ${ }^{(1-3)}$. Apocrine hidrocystomas are benign cystic lesions derived from the sweat glands of Moll and seldom found in the orbit. They are usually yellow-to-white (sometimes with layering) but less commonly blue to black (due to the Tyndall effect from the turbid contents), typically arise at the eyelid margins particularly around the inner canthus of the eyelid where the glands of Moll are located. Apocrine hidrocystomas are seldom found in the orbit ${ }^{(2-6)}$. The pathophysiology of hidrocystomas is uncertain. It has been hypothesized that sequestration of epithelial cells at the embryonic stage or traumatic implantation of epithelial cells into deeper tissues, including orbit, could lead to the condition ${ }^{(2-3)}$.

The authors report an atypical case of orbital apocrine hidrocystoma in superomedial orbit, highlighting the immunohistochemistry analysis and reviewing the literature.

\section{Case Report}

A 61-year-old female presented with a 5-year history of a painless mass in superomedial right orbit. The patient reported slow growth until 2 years prior to her examination, when the lesion seemed to have grown more rapidly and became increasingly firm. There was no history of impaired vision, diplopia, watering, discharge, or prior trauma. Visual acuity was normal. External examination revealed a palpable mass in the superomedial orbit along the medial orbital wall. It did not appear to be attached to the periorbital rim. There was no proptosis. Valsalva test was negative and extraocular motility was normal (Figure $1 \mathrm{~A}$ and $\mathrm{B}$ ). A CT study with axial and coronal slices showed an extraconal nodule, with partially defined limits, with internal heterogeneities areas, measuring about $1.6 \times 1.1 \mathrm{~cm}$, with discrete heterogeneous enhancement by contrast, in the superomedial orbit. (Figure $1 \mathrm{C}$ and $\mathrm{D}$ ).

The lesion was removed by an anterior orbitotomy approach. A retroseptal cystic mass was found, extended posteriorly along the levator aponeurosis. It was easily released and the intraoperative revealed a very thin-walled cystic mass that ruptured during the procedure with the release of a clear fluid (Figure $2 \mathrm{~A}$ and B). All the cystic wall was excised. During 6 months follow-up there has been no recurrence of the tumor.

\section{Histologic and immunopathological findings}

The histopathological analysis of the cyst wall revealed a cystic thin wall with double layer epithelium with an internal layer of cuboidal cells with opaque, densely eosinophilic cytoplasm exhibiting apical snouts (decapitation secretion). These findings were compatible with apocrine hidrocystoma (Figure $2 \mathrm{C}$ and $\mathrm{D}$ ).

Immunohistochemistry analysis was done to confirm the diagnosis. The cytokeratin-7 (CK7) and gross cystic disease fluid protein-15 (GCDFP-15) was positive and the immunostaining for S100 protein was negative in the analysis, confirming the prior diagnosis.

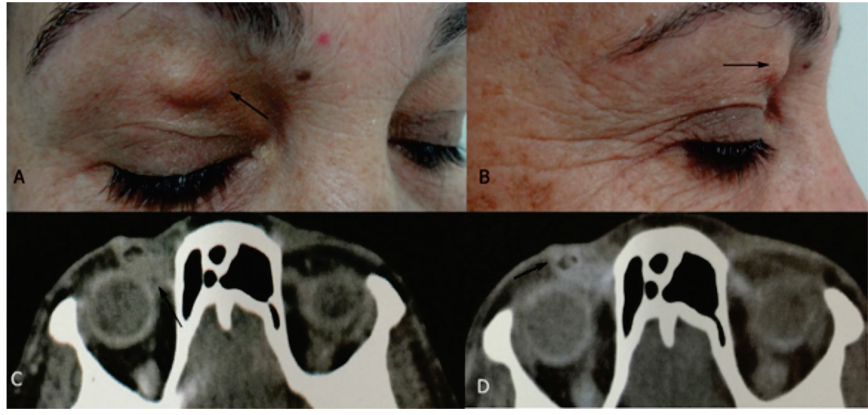

Figure 1: Orbital apocrine hidrocystoma. A: External examination revealed a palpable mass (arrow) in the superiomedial orbit along the medial orbital wall. B: side view of mass (arrow). C: Axial CT reveals an extraconal nodule, with partially defined limits, with internal heterogeneites areas (arrow), measuring about $1.6 \times 1.1 \mathrm{~cm}$ in superomedial orbit. D: CT with contrast revealed discrete heterogeneous enhancement by contrast (arrow).

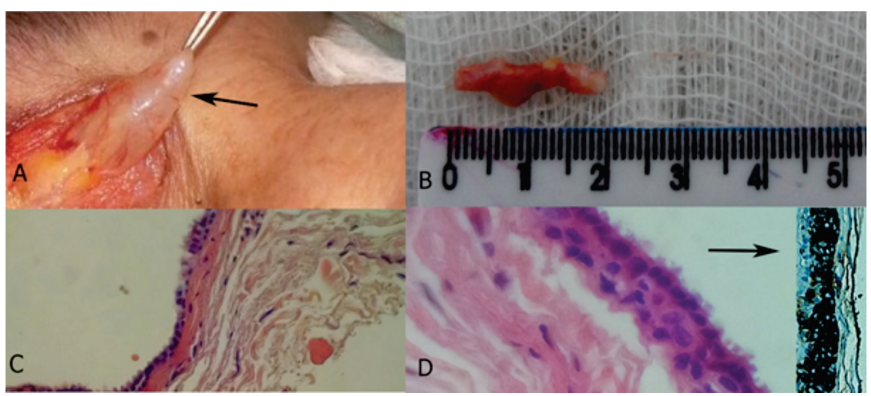

Figure 2: Orbital apocrine hidrocystoma. A: Intraoperative aspect of tumor (arrow). B: cystic wall measure $2 \times 0.5 \mathrm{~cm}$. C: Hematoxylineosin $\mathrm{x} 40$ revealed thin cystic wall with double layer ephitelia. D: Hematoxylin-eosin $\mathrm{x} 400$ revealed a double layer coating epithelium with an internal layer of cuboidal cells with opaque, densely eosinophilic cytoplasm exhibiting apical snouts (decapitation secretion). The arrow shows gross cystic disease fluid protein 15 positive.

\section{DisCUSSION}

Apocrine hidrocystomas are benign cystic lesions derived from the sweat glands of Moll and seldom found in the orbit. In this case, we report an apocrine hidrocystoma found in the superomedial wall of the orbit ${ }^{(1-4)}$. Although orbital cystic lesions are often encountered, they are mostly dermoid cysts and mucoceles. Apocrine hidrocystomas are extremely rare. The pathophysiology of hidrocystomas is uncertain. It has been hypothesized that sequestration of epithelial cells at the embryonic stage or traumatic implantation of epithelial cells into deeper tissues, including orbit, could lead to the condition. In our case, the lesion was acquired and there was no history of trauma or any prior surgical procedures ${ }^{(3-8)}$.

The CT findings revealed an extraconal nodule in the superomedial wall of the orbit, with cystic and solid areas. The intraoperative findings revealed a very thin-walled cystic mass that ruptured during the procedure with the release of a clear fluid and all of the cystic wall was excised. Ssi Yan Kai et al ${ }^{(8)}$ reported a case of recurrent giant orbital apocrine hidrocystoma after 2-years of primary excision, though the cystic wall was probably not completely excised.

The histopathological findings were compatible with apocrine hidrocystoma. Sometimes it is difficult to differentiate 
(the more common) eccrine from the apocrine hidrocystoma. In our case, deeply eosinophilic cytoplasm, apical snouts with decapitation secretion, a multilaminar epithelial cyst lining, CK-7 and GCDFP-15 markers positivity (an excellent marker for apocrine differentiation), unequivocally distinguish this lesion from the more common eccrine hidrocystoma. The eccrine hidrocystoma arises from the eccrine sweat gland ducts. It contains clear or faintly eosinophilic material and is lined by a double layer of low, pale cuboidal cells without papillations, no apical decapitation secretion, as was found in our study. The S100 protein is generally positive in eccrine glands, another fact that confirms our diagnosis ${ }^{(2)}$.
Orbital apocrine hidrocystomas have been described in the global literature (Table 1 ). Vignes et al. ${ }^{(1)}$ reported a 33-year-old man with an intraorbital, extraconal cystic lesion, where the histopathological examination revealed apocrine hidrocystoma. Valenzuela at al..$^{(7)}$ and Behshad et al..$^{(3)}$ reported a case of a man with cystic mass in the extraconal orbit, compatible with apocrine hidrocystoma upon histopathological examination. Ferraz et al. ${ }^{4}$ reported three cases of orbital apocrine hidrocystoma presenting with blepharoptosis, also confirmed with histopathological examination. In all these cases, the immunohistochemistry was not done to confirm the diagnosis. Jakobiek et $\mathrm{al}^{(2)}$ reported a case of palpebro-orbital apocrine hidrocystoma with immunochemistry diagnosis differentiation, as reported in our study.

Table 1

All cases of orbital hidrocystoma reported in the literature

\begin{tabular}{|c|c|c|c|c|c|}
\hline Author & Patient & Location & CT findings & Pathologic finds & IHC findings \\
\hline Vignes et al. ${ }^{1} 2007$ & Male, 33y & $\begin{array}{l}\text { Intraorbital, } \\
\text { extraconal }\end{array}$ & $\begin{array}{l}\text { Intraorbital, extraconal, } \\
\text { cystic lesion }\end{array}$ & $\begin{array}{c}\text { Eosinophilic cytoplasm, } \\
\text { a multilaminar epithelial } \\
\text { cyst lining. }\end{array}$ & IHC was not done \\
\hline Jakobiek et al. ${ }^{2} 2010$ & Female, $57 \mathrm{y}$ & $\begin{array}{l}\text { Anterior orbit, } \\
\text { left upper eyelid }\end{array}$ & $\begin{array}{l}\text { Cystic superonasal } \\
\text { mass in the left upper } \\
\text { eyelid and the anterior } \\
\text { orbit extending to about } \\
\text { the equator of the globe }\end{array}$ & $\begin{array}{l}\text { Cyst contained an amorphous } \\
\text { eosinophilic material. } \\
\text { Double layer of cells without } \\
\text { mitotic activity or nuclear } \\
\text { pleomorphism. }\end{array}$ & $\begin{array}{l}\mathrm{CK} 7+\mathrm{SMA}+ \\
\mathrm{GCDFP} 15+ \\
\mathrm{CD} 34+ \\
\text { and CD68+ }\end{array}$ \\
\hline Valenzuela et al. ${ }^{7} 2011$ & Male, $41 y$ & $\begin{array}{l}\text { Intraorbital, } \\
\text { extraconal }\end{array}$ & $\begin{array}{l}\text { Intraorbital, extraconal, } \\
\text { cystic lesion }\end{array}$ & $\begin{array}{l}\text { Eosinophilic cytoplasm, } \\
\text { a multilaminar epithelial } \\
\text { cyst lining, decapitation } \\
\text { secretion }\end{array}$ & IHC was not done \\
\hline Ssi-Yan-Kai et al. ${ }^{8} 2012$ & Female, 46y & $\begin{array}{l}\text { Intraorbital, } \\
\text { extraconal, } \\
\text { medial wall }\end{array}$ & $\begin{array}{l}\text { A large, cystic mass of } \\
\text { about } 18 \text {-mm diameter } \\
\text { occupying the infero- } \\
\text { nasal orbital quadrant }\end{array}$ & $\begin{array}{l}\text { No description, just the } \\
\text { diagnosis of apocrine } \\
\text { hidrocystoma }\end{array}$ & IHC was not done \\
\hline Behshad et al. ${ }^{32} 2015$ & Male, $41 y$ & $\begin{array}{l}\text { Intraorbital, } \\
\text { extraconal, } \\
\text { supero-medial } \\
\text { orbit }\end{array}$ & $\begin{array}{l}\text { A well-defined cystic } \\
\text { lesion localized in the } \\
\text { supero-medial } \\
\text { anterior orbit }\end{array}$ & $\begin{array}{c}\text { No description, just the } \\
\text { diagnosis of apocrine } \\
\text { hidrocystoma }\end{array}$ & IHC was not done \\
\hline \multirow[t]{3}{*}{ Ferraz et al. ${ }^{4} 2015$} & Male, 46y & $\begin{array}{l}\text { Right supraorbital } \\
\text { margin }\end{array}$ & No description & $\begin{array}{l}\text { Single tall columnar } \\
\text { cuboidal cell epithelial } \\
\text { layer with apical snouting } \\
\text { in the lining cells and } \\
\text { decapitation secretion }\end{array}$ & IHC was not done \\
\hline & Female, $17 \mathrm{y}$ & $\begin{array}{l}\text { Among the fibers } \\
\text { of the levator muscle }\end{array}$ & No description & $\begin{array}{l}\text { Simple columnar } \\
\text { epithelium and } \\
\text { decapitation secretion }\end{array}$ & \\
\hline & Man, 67y & $\begin{array}{l}\text { Adherent to } \\
\text { levator muscle }\end{array}$ & No description & $\begin{array}{l}\text { Dual-layered epithelial } \\
\text { cells and the absence of } \\
\text { goblet cells in the cyst wall }\end{array}$ & \\
\hline
\end{tabular}

Y: years; IHC: immunohistochemistry; +: positive; CK7 citoqueratin 7; GCDFP15: Gross cystic disease fluid protein 15; SMA: smooth muscle actin; -: negative. 
In some cases, just the immunohistochemistry (Chart 1) could differentiate eccrine or apocrine hidrocystomas or conjunctival cysts. The CK7 is a non-queratinizated simple epithelium cytokeratin. It is positive in ephitelia ducts and glands. The GCDFP-15 is an excellent marker for apocrine differentiation. It is present in apocrine epithelia, which will differentiate it from eccrine epithelia. Immunohistochemical demonstration of GCDFP-15 has become a useful adjunctive diagnostic tool in cases where decapitation secretion is not readily apparent, although in our study the histological analysis revealed the decapitation secretion. The S100 protein derives from neural crest cells, like Schwan cells, melanocyte and inner layer of eccrine glands. In our study, the CK7 and GCDFP15 were positive and the S100 protein was negative, which confirm definitively our diagnosis of orbital apocrine hidrocystoma ${ }^{(1-10)}$.

\section{Chart 1}

Immunohistochemical markers used to differentiate apocrine from eccrine hidrocystomas

\begin{tabular}{ll}
\hline \multicolumn{1}{c}{ Immunohistochemical markers } & \multicolumn{1}{c}{ Function summary } \\
\hline Citokeratin 7 (CK7). & $\begin{array}{l}\text { Type II keratin of simple non-keratinizing epithelia. The cytokeratin } 7 \text { is a } \\
\text { positive marker in glandular epithelium. }\end{array}$ \\
Gross Cystic Disease Fluid Protein 15) (GCDFP15) & $\begin{array}{l}\text { Also called BRST2, prolactin-induced protein (PIP). It is an excellent } \\
\text { marker of apocrine differentiation. It is a glycoprotein originally isolated in } \\
\text { human breast gross cystic fluid. }\end{array}$ \\
S100 Protein (S100) & $\begin{array}{l}\text { Acidic protein, } \mathbf{1 0 0} \% \text { Soluble in ammonium sulfate at neutral pH (derivation } \\
\text { of name). It is present in eccrine glands inner layer. Common marker of } \\
\text { neural tissue / lesions and melanoma. }\end{array}$ \\
Smooth Muscle Actin (SMA) & $\begin{array}{l}\text { Identify myoepithelial cells in normal, neoplastic or diseased breast, salivary } \\
\text { glands or sweat glands. }\end{array}$ \\
\hline
\end{tabular}

Although rare, apocrine hidrocystomas should be considered in the differential diagnosis of cystic mass of the orbit in any age group.

\section{RefERENCES}

1. Vignes JR, Franco-Vidal V, Eimer S, Liguoro D. Intraorbital apocrine hidrocystoma. Clin Neurol Neurosurg. 2007;109(7):631-3.

2. Jakobiec FA, Bhat P, Kropp TM. Palpebro-orbital apocrine cystadenoma: immuno- histochemical verification of a unique variant with a critical differential diagnosis. Ophthal Plast Reconstr Surg. 2010;26(4):245-9.

3. Behshad S, Weil NC, Ho ST, Mayhall GK, Valenzuela AA. A Cyst you can't miss: a rare presentation of an orbital apocrine hidrocystoma. Orbit. 2015;34(4):229-31.

4. Ferraz LB, Burroughs JR, Satto LH, Natsuaki KL, Meneguin RL, Marques ME, Schellini SA. Three adult cases of orbital hidrocystoma presenting with blepharoptosis. J Clin Med. 2015;4(1):150-8

5. Yasaka N, Iozumi K, Nashiro K, Tsuchida T, Seki Y, Furue M, Takayama O,Shimada S, Tamaki K. Bilateral periorbital eccrine hidrocystoma. J Dermatol. 1994;21(7):490-3.
6. Mims J, Rodrigues M, Calhoun J. Sudoriferous cyst of the orbit. Can J Ophthalmol. 1977;12(2):155-6.

7. Valenzuela AA, Heathcote JH. Apocrine hidrocystoma of the orbit. Orbit. 2011; 30(6):316-7.

8. Ssi-Yan-Kai IC, Pearson AR. Recurrent giant orbital apocrine hidrocystoma. Eye. 2012 ;26(6):895-6.

9. Rosen WJ, Li Y. Sudoriferous cyst of the orbit. Ophthal Plast Reconstr Surg. 2001;17(1):73-5.

10. Saunders JF. Congenital sudoriferous cyst of the orbit. Arch Ophthalmol. 1973;89(3):205-6.

\section{Corresponding author:}

Eduardo Damous Feijó

Hospital Oftalmológico de Anápolis - Av. Faiad Hanna, 235.

Cidade Jardim, Anápolis, GO, Brazil. Zip code: 75080-410.

Email: eduardodff@yahoo.com.br 